\title{
Reading the Story of Jesus Christ as an Epic
}

\author{
Wangari Mwai, Edwin Gimode, Charles Kebaya \\ Kenyatta University, Nairobi, Kenya
}

\begin{abstract}
There is no doubt that Jesus Christ is the eternal embodiment of the Christian faith. The story of salvation, especially the life of Jesus, forms the basis through which many Christians encounter the eternal. Indeed, each facet of Christ is intricately intertwined with the others and that Christian literature often focuses on redefining various figures in the image of Christ and on illustrating morality. Without disparaging in any way the story of Jesus Christ, this paper parallels the conceptualization of epic heroism and the narrative of Jesus Christ. In doing this, the article provides a critical exegesis of elements of epic heroism in the story of Christ. Ultimately, reading the story of Jesus Christ through the prism of epic heroism helps us submit that it is a "tale of Christian identity" comparable to the epic identity and able to convey eternal meaning to Christian groups who recognize it as "their story of salvation”.
\end{abstract}

Keywords: epic, epic heroism, Jesus Christ, Christian identity

\section{Conceptualizing the Epic in Literary Scholarship}

This article focuses on reading the story of Jesus Christ as an epic. Epics usually rank very high among literary and traditional genres. They are great narratives or superstories that excel in length, power of expression, and weight of content compared with other narratives (Honko, 1996). Their value, however, derives less from their literal content than from their cultural context and function: they are seen in relation to something beyond their text, such as people's perception of group identity, core values of the society in question, models of heroic conduct and human endeavor, symbolic structures of history and mythology. This means that a rather tedious and repetitive narrative may also attain greatness in the consciousness of the particular group that identifies itself with the personages and events of the epic. Thus the reception of epics is part and parcel of their existence. Without social approval and even enthusiasm registered by at least some group, it becomes difficult to place a narrative in the category of epic (Honko, 1993). Epics in this sense exist primarily in the old world. As innovation by performers is admired, it is not surprising that very different versions of the same epic exist. In some instances, individual passages are expanded, contracted or altered. This is the kind of analysis that this article seeks to carry out regarding the story told on the life and times of Jesus Christ the hero in the Bible.

Literary scholars define an epic as a narrative couched in poetic language, subject to special linguistic rules of form celebrating the feats of a legendary or traditional hero (Harmon \& Holman, 1992; Finnegan, 1987). It is further described as a literary or dramatic composition that resembles an extended narrative poem

Wangari Mwai, Ph.D., Professor of Literature, Literature Department, Kenyatta University.

Edwin Gimode, PhD., Senior Lecturer, Department of History, Archaeology and Political Studies, Kenyatta University.

Charles Kebaya, M.A., Lecturer, Department of Film and Theatre Arts, Kenyatta University.

Correspondence concerning this article should be addressed to Wangari Mwai, Ph.D., Literature Department, Kenyatta University, P.O Box 43844-00100, Nairobi, Kenya, e-mail: mwai.wangari@ku.ac.ke. 
celebrating heroic feats. Thus an epic is both a poem and a long narrative, told in an elevated style of language, focuses on the exploits of a hero or demi-god who represents the cultural values of a people. It also contains superhuman feats of strength or military prowess, and often times, gods or supernatural beings take part in the action. Traditionally, the term epic applied most accurately to classical Greek texts like the Iliad and the Odyssey. However, over time, the term has been extended by literary scholars and critics to embrace other genres. For instance, Shakespeare's various History Plays have been collectively called an epic of Renaissance Britain. Other examples include Biblical stories like that of Moses, the epic hero of the book Exodus.

Finnegan (1992) opines that the traditional definition of the epic does not fit into the literary genres found in Africa. She says "At least, in the more obvious sense of a "relatively long narrative poem", epic hardly seems to occur in sub-Saharan Africa apart from forms like the written Swahili Utenzi which are directly attributable to Arabic literary influence" (Finnegan, 1992, p. 108). However, the extension of the confines of the genre has embraced this tradition in Africa and identified components of the same as widely available in the continent. Currently, in the African oral literary tradition, the epic is also a popular genre especially in West Africa where praise poetry was common. Praise poetry was sung in the courts of kings and was used to tell of exploits of heroes. Epic creations from the continent include such as Shaka the Zulu from South Africa, and Niane's/Mapanje Sundiata of Mali. Other examples include the Swahili Utendi tradition. This name is drawn from the great epic tradition of tendi drawn from the word tenda or take action (Mwai, 2010). They include Utendi wa Mwanakupona, Utendi wa Muhammadi, Utendi wa Herekali, Utendi wa Inkishafi, Fumo Liongo Fumo (Knappert, Four Centuries Of Swahili Verse) and others such as Mekatilili among others. Most importantly, epics have a unique connection to the community as Susan Wadley (1991) points out "Epics have a unique relationship with the community in which they are performed: they are 'our story', and stand apart from other songs and stories because of community identification with them” (p. 220). The epic's richness emanates from this cultural concentration which in turn explains the complexity of the genre.

In spite of the more or less pronounced tendencies of an epic, the epic hero is the main character in an epic poem - typically one who embodies the values of his or her culture. For instance, Odysseus is the epic hero in the Greek epic called The Odyssey in which he embodies the cleverness and fast-thinking Greek culture admired. Aeneas is the epic hero in the Roman epic The Aeneid in which he embodies the pietas, patriotism, and the four cardinal virtues the Romans admired. If we stretch the term epic more broadly beyond the strict confines of the Greco-Roman tradition, we might read Beowulf as loosely as an epic hero of Beowulf, Moses as the epic hero of Exodus and Jesus Christ as the hero of the Synoptic Gospels. This article discovers the extent to which the typical motifs found in epics are to be found in the hero story of Jesus Christ.

Elements of epic heroism are best referred to as motifs. Finnegan (1987) points out those motifs include plots, subject matter, types of character and action. A motif is therefore a conspicuous recurring element, such as a type of incident, a device, a reference, or verbal formula, which appears frequently in works of literature. For instance, in folk tales, the crafty hare is a motif because he often appears as a common character. The broom is also a motif in narratives that have witches as characters. Frequently, literary critics use the word motif interchangeably with term leit-motif. In its original form, this was a "short, constantly recurring musical phrase associated with a particular person, place, or idea” (Honko, 1996). The spelling leitmotif is an anglicization of the German Leitmotiv, literally meaning "leading motif”, or perhaps more accurately, "guiding motif”. In relation to our discussion, this concept is used by literary or dramatic critics to refer to a recurring event, image, object or character in a story, poem, film or play. Leitmotifs (or motifs) become significant to the 
meaning of the overall work when they develop thematic importance.

The story line of the epic hero is dotted with motifs that recur within it (Njozi, 1999). Motifs in the story of the epic hero include; the miraculous conception, self sacrifice, heroic and miraculous deeds and the journey motif. In general the characteristics of an epic hero are:

- An epic hero is larger than life figure from a history or legend,

- Usually favored by or even partially descended from deities, but aligned more closely with mortal figures in popular portrayals.

- The hero participates in a cyclical journey or quest, faces adversaries that try to defeat him in his journey, gathers allies along his journey, and returns home significantly transformed by his journey.

- The epic hero illustrates traits, performs deeds, and exemplifies certain morals that are valued by the society from which the epic originates. They usually embody cultural and religious beliefs of the people.

- Many epic heroes are recurring characters in the legends of their native culture. Epic heroes are superhuman in that they are smarter, stronger, and braver than average humans. An epic hero can also be a warrior of some sort who performs extraordinary tasks that most find difficult. This hero is strong, smart, and brave.

The key questions this article responds to are: To what extent are elements of epic heroism or motifs present in the story of Jesus? Does the character of Jesus Christ depict him as an epic hero?

\section{Jesus Christ: The Epic Hero}

The following motifs constitute the key ways in which the story of Christ can be read as an epic:

\section{The Miraculous Birth Motif}

Epic heroes are superhuman beings. Jesus Christ is believed to be larger than life character. Jesus Christ was anticipated for thousands of years before His birth and remains a hero today. Much of this has been attributed to His being the "Son of God" thus a descendant of a deity. This happened through the virgin birth. By “virgin birth” Protestants generally mean "virginal conception”. Roman Catholicism and Orthodoxy believe also in a literal virgin birth, whereby the baby passed out of Mary's body in such a way as to leave her virginity anatomically unimpaired. This belief is found first in writings of Syrian origin from the mid-2nd century, such as the protevangelium of James. It quickly became a standard part of doctrine of Mary's "perpetual virginity", that is, including virginity postpartum, "after giving birth" to Jesus, so that "the brethren of the Lord" could not have been Mary’s children. The Reformers were virtually unanimous in holding to Mary's perpetual virginity. This article will follow common practice in using "virgin birth" to denote virginal conception.

The details of the birth of Jesus are recorded only in the Gospels of Mathew and Luke, each Gospel clearly using different sources, that of Matthew concentrating more on Joseph's side of the story, while Luke shows an intimate knowledge of Mary's experiences and of those of her relative Elizabeth, mother of John the Baptist which it is generally agreed could only have been derived, directly or indirectly, from Mary herself. The two accounts of the birth of Jesus in Matthew and Luke are clearly independent of one another, and both record that he was born through the direct action of the Holy Spirit, without a human father (Matthew 1: 18-25; Luke 1:34). So the only two gospels that record the circumstances of Jesus' birth present him as born from a virgin—although greater stress falls on conception by the Holy Spirit than on Mary's virginity. It is therefore the more remarkable that on the crucial fact of the supernatural origin of Jesus' birth, without a human father, 
the two Gospels with their independent sources are agreed.

The circumstances of Jesus' birth and childhood were in striking contrast to the super-natural mode of his conception. He was born in the animal quarters of a crowded village inn, and brought up in a very ordinary home in the obscure Galilean village of Nazareth, which had achieved no mention in earlier literature. His family may have been what we would call "middle class", the "carpenter" (actually more a building contractor) being a skilled craftsman, perhaps employing labour, and a respected figure in village life. But the Gospel records make it clear that they were not affluent (Luke 2:24; cf. Leviticus 12:8) and Jesus' parables sometimes reflect experience of a home where comfort and money were limited such as in (Luke 11.5-7; 15:8-10).

The fact that Joseph is not mentioned after the birth and childhood stories, and that Jesus was referred to in the village as "Mary's son” (Mark 6:3), is often taken to mean that Joseph died while Jesus was young, leaving Jesus as the oldest son to run the family business and provide for his four younger brothers and unknown number of sisters (Mark 6:3). In such circumstances, Jesus could not aspire to a higher education. His full knowledge of the Old Testament scriptures attests to his having received the normal Jewish child's education at the village synagogue-school, and the one story of his childhood preserved in the Gospels indicates an abnormal aptitude in matters of religious debate (Luke 2:42-50). Beyond this we know nothing of his childhood, though his later teaching shows a mind well stocked with the incidents and characters of daily life in a country village. It is all the more remarkable that on the crucial fact of the supernatural origin of Jesus' birth, without a human father, the two Gospels with their independent sources agree:

Behold, you will conceive in your womb and bear a son, and you shall name him Jesus. He will be great and will be called Son of the Most High, and the Lord God will give him the throne of David, his father, and he will rule over the house of Jacob forever, and of his kingdom there will be no end". But Mary said to the angel, "How can this be, since I have no relations with a man?” And the angel said to her in reply, “The Holy Spirit will come upon you, and the power of the Most High will overshadow you. Therefore the child to be born will be called holy, the Son of God.” (New American Bible, Luke 1:26-36)

In Christian theology, the above scripture is labelled the annunciation. The Annunciation (anglicised from the Latin Vulgate Luke 1:26-39 Annuntiatio nativitatis Christi), also referred to as the Annunciation to the Blessed Virgin Mary, the Annunciation of Our Lady or Annunciation of the Lord, is the Christian celebration of the announcement by the angel Gabriel to the Virgin Mary that she would conceive and become the mother of Jesus, the Son of God, marking his Incarnation. Gabriel told Mary to name her son of Yehoshua, meaning "YAHWEH is salvation". Many Christians observe this event with the Feast of the Annunciation on 25 March, nine full months before Christmas, the ceremonial birthday of Jesus. According to Luke 1:26, the Annunciation occurred "in the sixth month" of Elizabeth's pregnancy with John the Baptist. Irenaeus (c. 130-202) of Lyon regarded the conception of Jesus as 25 March coinciding with the Passion.

The annunciation story helps us to understand the concepts of the miraculous conception of Jesus in the womb of Mary and the miraculous birth of Jesus without impairment to the virginity of Mary. This is also referred to as The Miraculous Conception and Virgin Birth of Jesus and The Divine Motherhood and Perpetual Virginity of Mary. In Christian rituals and ceremonies, this is observed during each Advent season. Christians reflect on the prophetic words of Isaiah that a virgin will be with child and bear a son, and she will call His name Emmanuel (Isaiah 7:14), and also on St. Luke’s Gospel passage of the Annunciation. The Virgin Mary will become a mother. Thus, through Mary, Jesus was to acquire his human or anthropological nature.

In a seeming contradiction, Mary was still to remain a virgin, Mary responds that she does not know man 
and the angel declares the son to be born of her will be the Son of God. The Virgin Mary was to conceive by the power of the Holy Spirit; that means Jesus was conceived in the womb of Mary supernaturally, without the seed or assistance of any man. And if Jesus is conceived in a supernatural way, does not it make sense that He is born, too, in that same miraculous way. Both events transcend the natural order of things and highlight the divine Theo' or supernatural nature of Jesus. How does a human person give birth to divine one, two totally different natures? This is the splendid and divine unity. The truth is that Jesus is not either or but both and, both fully God and fully man, a Theo- Anthropological nature.

\section{The Cultural Hero Motif}

Epic heroes are best known for propagating some values and beliefs of a given well known community. Their times and lives are a landmark in the society's history. At the societal level, however, the epic, in the strict sense, is situated within a certain location and as a function to perform where it becomes the supreme truth and relates directly to the identity of the group. The Nativity of Jesus refers to the accounts of the birth of Jesus, primarily based on the two accounts in the gospels of Luke and Matthew, and secondarily on some apocryphal texts. The canonical gospels of Luke and Matthew describe that Jesus was born in Bethlehem in Judea, to a virgin mother. In the Gospel of Luke account, Joseph and Mary travel from Nazareth to Bethlehem for the census, and Jesus is born there and laid in a manger. Angels proclaim him a savior for all people, and shepherds come to adore him. In the Matthew account, astronomers follow a star to Bethlehem to bring gifts to Jesus, born the King of the Jews. King Herod orders the massacre of all the boys less than two years old in Bethlehem, but the family flees to Egypt and later settles in Nazareth. Many scholars view the two narratives as non-historical and contradictory. Other traditional Christian scholars maintain that the two accounts do not contradict each other, pointing to the similarities between them. Some scholars view the discussion of historicity as secondary, given that gospels were primarily written as theological documents rather than chronological timelines.

In Christian theology, the Nativity of Jesus concerns the incarnation of Jesus as the second Adam, in fulfilment of the divine will of God, undoing the damage caused by the fall of the first man, Adam. The Artistic depiction of Nativity has been a major subject for Christian artists since the fourth century. Since the 13th century, the Nativity scene has emphasized the humility of Jesus and promoted a tenderer image of him, as a major turning point from the early "Lord and Master" image, affecting the basic approaches of Christian pastoral ministry. Nevertheless, the birth narratives do contain some useful biographical information, e.g., Jesus' being born near the end of Herod's reign and his father's being named Joseph are considered historically plausible. Some prominent, contemporary Christian scholars maintain the traditional view, arguing that the two accounts are historically accurate and do not contradict each other, pointing to the similarities between the two accounts, such as the birthplace of Bethlehem and the Virgin Birth.

Sources also defend the historicity of the massacre. France (1997) observes that the massacre was a low magnitude event in nature that would have not demanded the attention of Josephus but was in line with Herod's character. Maier (1988) is quoted arguing that Bethlehem was small, and the massacre would have been too small for Josephus to have heard of it given that it allegedly took place over 40 years before the birth of Christ. Barnett (2005) and (2014) also state that Bethlehem was a very small village with few inhabitants, and the massacre would have involved too few children to have been recorded by historians in general. The New Bible Dictionary (2004) both Luke and Matthew associate Jesus' birth with the time of King Herod. Most scholars 
generally assume a date of birth between 6 and 4 BC. However, the Gospel of Luke also dates the birth 10 years after Herod's death, during the census of Quirinius in 6 AD described by the historian Josephus.

\section{The Journey or Quest Motif}

The monomyth, or the hero's journey, is a basic pattern that is arguably found in most hero narratives from around the world. Campbell (2008) describes seventeen (17) stages or steps along this journey. Very few myths contain all these stages - some epics contain many of the stages, while others contain only a few; some may focus on only one of the stages, while others may deal with the stages in a somewhat different order. These stages may be organized in a number of ways, including division into three sections: Departure (sometimes called Separation), Initiation, and Return. Departure deals with the hero's adventure prior to the quest; Initiation deals with the hero's many adventures along the way; and Return deals with the hero's return home with knowledge and powers acquired on the journey.

In normal cases of departure, a hero ventures forth from the world of common day into a region of supernatural wonder: Fabulous forces are encountered there and a decisive victory is won. The hero comes back from this mysterious adventure with the power to bestow gifts on his fellow man. The story of Jesus Christ has various types of journeys; both physical and spiritual. For one, His departure is believed to have been His initial journey from heaven to earth. The story of Jesus Christ shows Him accepting to undertake the journey after God asked in heaven "Who will I send?" and Jesus answered "Here I am O Lord Send me”. This is best explained through the miraculous birth motif. In a most departure monomyths, the hero begins in the ordinary world, and receives a call to enter an unknown world of strange powers and events. The hero begins in a mundane situation of normality from which some information is received that acts as a call to head off into the unknown. Although Jesus Christ took diverse journeys both physical and spiritual, it is clear that His departure was different. He began from supernatural to natural. However, to Him, the world was unknown and with strange evil powers that He was not accustomed to.

Often when the call is given, the future hero first refuses to heed it. This may be from a sense of duty or obligation, fear, insecurity, a sense of inadequacy, or any of a range of reasons that work to hold the person in his or her current circumstances. It is only later that the person accepts to journey and enters a new strange world for the initiation stage. During the quest, he must face tasks and trials, either alone or with assistance. The assistance is introduced once the hero has committed to the quest, consciously or unconsciously, a guide and magical helper appears, or becomes known. More often than not, this supernatural mentor will present the hero with one or more talismans or artifacts that will aid them later in their quest. In the most intense versions of the narrative, the hero must survive a severe challenge, often with help. If the hero survives, he may achieve a great gift. The hero must then decide whether to face the return stage with this gift. If the hero does decide to return, he or she often faces challenges on the return journey. If the hero returns successfully, the gift may be used to improve the world. Once the hero has committed to the quest, consciously or unconsciously, his guide and magical helper appear, or become known. More often than not, this supernatural mentor will present the hero with one or more talismans or artifacts that will aid them later in their quest.

Diverse activities leading to the initiation of Jesus into the journey of a hero are recorded in different gospels. For instance, Luke records that since the age of twelve (Luke 2:42), Jesus disappears only to reappear at the age of 30 for baptism and thus initiation to task ahead of Him:

Now when all the people were baptized, it came to pass, that Jesus also being a baptized, and praying, the heaven was 
opened, and the Holy Ghost descended in a bodily shape like a dove upon him, and a voice came from heaven, which said, Thou art my beloved Son; in thee I am well pleased ( Luke 3: 21).

He is then driven to the wilderness where He undergoes a transition as He spiritually journeys through prayer and fasting. When he enters the wilderness after his baptism, Jesus is tempted by Satan. Here Satan guards the threshold to Jesus' full service to God. Will Jesus use God's power for his own ends? Will he give in to hunger and turn stones into loaves? Will he test God's powerful authority by throwing himself from a high place? Will he place his trust in Satan, worshiping the Devil to gain power God has already promised? Three times Jesus is tested and three times Jesus offers faithful responses. Satan has been defeated, and Mark records that Jesus "was with the wild beasts, and the angels were ministering to Him" (Mark 1:13). Through this scene, we get a sense of the cosmic nature of Jesus' mission, that Satan himself will oppose Jesus. Indeed, the rest of Jesus life and ministry he will face off against Satan over and over again. This acts as a spring board to His mission because at end of it, He announces His mission. John also documents the baptism as a launching pad for the ministry but not the wilderness experience.

When on earth, Jesus journeys through the road of trials and is a series of tests, tasks, or ordeals that the person must undergo to begin the transformation. Often the person fails one or more of these tests, which often occur in threes. It comes after the hero's acceptance to move on and has to undergo challenges. Jesus was tested by the Pharisees, Sadducees and teachers of the law over and over again in Jerusalem. Each time, Jesus offered a creative teaching or response that not only escaped the trap, but offered additional insights into God and the Kingdom. Jesus underwent this especially through lack of acceptance, various plans and attempts at His life, and lastly the crucifixion. The crucifixion leads Him to another monomyth of dying and being in a tomb for three days. In normal studies of the myth, this is referred to as the stage of the belly of the whale. It represents the final separation from the hero's known world and self. By entering this stage, the person shows willingness to undergo a metamorphosis. The idea that the passage of the magical threshold is a transit into a sphere of rebirth is symbolized in this worldwide womb image of the belly of the whale. The hero, instead of conquering or conciliating the power of the threshold, is swallowed into the unknown and would appear to have died. This popular motif gives emphasis to the lesson that the passage of the threshold is a form of self-annihilation. Instead of passing outward, beyond the confines of the visible world, the hero goes inward, to be born again.

Jesus decision to die came after a time of near refusal and loneliness. This is considered His greatest battle in the Garden of Gethsemane. Though he asks his disciples to watch with him, ultimately Jesus must face the ordeal alone. This is referred to as the Gethsemane experience as recorded in the gospel of Matthew below:

Then cometh Jesus with them unto a place called Gethsemane, and saith unto the disciples, Sit ye here, while I go and pray yonder. And he took with him Peter and the two sons of Zebedee, and began to be sorrowful and very heavy. Then saith he unto them, my soul is exceeding sorrowful, even unto death: tarry ye here, and watch with me. And he went a little further, and fell on his face, and prayed, saying, O my Father, if it be possible, let this cup pass from me: nevertheless not as I will, but as thou wilt (Mathew 26:36).

After this, Jesus undergoes another journey in which He departs through death, burial and then a return to the world through resurrection. In the Christian faith, this marks His victory over death and the gift of eternal life is given to those in the world who accept Him. The journey motif in this narrative continues in that after return to the world, Jesus takes a final return journey to heaven where it is believed that He lives in glory awaiting the day to return yet again to the world to reward those who have obeyed Him on earth with the gift of 
eternal life.

In this regard, the Hero's Journey is a powerful model for understanding stories, and provides a useful set of tools for excavating meaning from the Bible as a whole and the New Testament in particular. Through the Hero's Journey, we catch glimpses of the deeper realities in the plan of God: working through Jesus to bring eternal life to humanity.

\section{The Sacrificial Self-Motif}

Sacrificing one's life is a common motif in epic narratives. The epic hero, it is known, sacrifices himself for others. To Christians, Jesus made an infinite sacrifice. His life is of infinite value and he gave it for the sins of all mankind. He left His home in glory and came down to earth so as to show human beings the way. His saving work is spoken of in sacrificial terms. In the Bible, He is spoken of as the slain lamb of God, whose precious blood takes away the sin of the world (John 1:29, 36; I Peter 1:18-19; Revelations 5:6-10; 13:8). More specifically, he is said to be the true Passover lamb-Pascha (I Corinthians. 5: 6-8) as a sin offering (per hamartias). The New Testament often identifies Jesus Christ with the suffering Servant. And with the Messiah who is to atone for iniquity. Christ also chose a horrible death freely (John 10:18), saying, "Greater love has no man than this, that a man lay down his life for his friends” (John 15:13).

\section{The Heroic/Miraculous Deeds Motif}

The recordings of the life of Jesus Christ describe him as one who healed people from sickness, madness and death. According to the gospel, Jesus healed the multitudes of every illness and raises them from the dead. Jesus' works are clearly marked off from others by their manner or mode. Whereas prophets did their work in the name of God or after prayer to God to cast, Jesus cast out demons and healed with the same air of rightful power as informed his pronouncement of forgiveness to the sinner (Mark 2:9 - 11). At the same time, Jesus stressed that his works were done in constant dependence in the very mark of the perfect unity of deity and humanity.

The New Testament teachings on the virgin birth, the resurrection and ascension emphasize the newness of what God did in Christ. He was born of a woman in the genealogy of Abraham and David, but of a virgin; others had raised from death, only to die again; he "always lives" and has ascended to the right hand of power. It is, moreover, true of the resurrection as of no other individual miracle that on it the New Testament rests the whole structure of faith (1 Corinthians 15:17). This event was unique as the decisive triumph over sin and death.

Christian and non-Christian sources attest to the fact that Jesus was known to his contemporaries as a worker of miracles. The vast majority of those recorded are cases of miraculous healing, and the Gospels present healing, often of large numbers of people, as a regular feature of Jesus' ministry (Mark 1:32-34; 3:7-12; 6:55f; Luke 7:21f). Often coupled with his healing miracles (though usually carefully differentiated from them, e.g. Mark 1:32-34; Luke 13:32) are his exorcisms. These activities were expected also of His disciples when they went out in his name (Mark 6:13; Matthew 10:8), and they are intrinsically related with his preaching, as aspects of a total onslaught on the powers of evil, in their physical as well as their spiritual manifestation.

Healing and exorcism were an accepted part of the activity of godly men within first-century Judaism, but nothing approaching the intensity of Jesus' healing ministry is recorded of any contemporary figure. The range of complaints he healed is very wide, from paralysis to blindness, and from leprosy to a severed ear. Three cases of restoring to life to those who had recently died are also recorded. Unlike some contemporary exorcists, 
he used little or no ritual, a mere word of command being often the only means employed (Matthew 8:8f, 16). The overwhelming impression was of his simple authority over physical and spiritual evil, and his compassion for those in need. His healing ministry was not a bid for recognition, nor was it primarily designed to prove anything, but it was the automatic response of his compassion to human need when he met it.

Jesus' other ("nature") miracles are comparatively few, but again the same pattern of an automatic and unselfconscious response to a pressing need can be seen in most of them, feeding hungry crowds, supplying wine in an emergency, providing fish after a night of fishing in vain, and calming a storm on the lake. That Jesus solved such problems by miraculous means was not so much a deliberate display of power as a natural result of who he was. Only the walking on water and the sudden withering of the fig-tree seem to have been performed more to teach the nature of his person and mission than to meet a definite need. The miracles, then, are not the proof of Jesus' divine nature, though they imply it. They are an inevitable part of a total ministry of deliverance and of the conquest of evil. The characteristics of His ministry make him an epic hero.

\section{Conclusions}

From the foregoing, it is clear that the story of the life of Jesus Christ, though it does not fulfill all the 17 stages of an epic as Campbell (2008) points out, can be read as an epic. This suggestion is no exception. Like all other epics, it fulfills some of the expectations of an epic hence deserves scholarly appreciation. Such expectations include the Journey Motif, Sacrificial self-Motif, Miraculous Birth Motif, Cultural Hero Motif and the Miraculous Deeds Motif. Most importantly, we have pointed out the personification of the journey of Jesus Christ as being critical in the salvation story and creates a sense of identity among Christian groups. The Gospels contain a host of elements that help us understand Jesus' salvation mission. Indeed, Christians believe that Christ sacrificed His joyous life in His heavenly home to come down to earth to suffer for them to be saved. He also gave His life as atonement for their sins so that they can inherit His home in heaven. It is for these reasons that Christians argue that one does not find their Self and then find Christ. Rather, people will discover their selves if they focus on the ultimacy of Christ. This follows Jesus' example, who had great clarity about his Self precisely because he is living not for his own will, but for God's. Therefore, the story of Jesus embodies a divine Hero and demonstrates sacrifices that His true heroes should try to emulate.

\section{References}

Albright, W. F., \& C. S. Mann. (1971). Matthew. The Anchor Bible Series. New York: Doubleday \& Company.

Bannet, P. (2005). Birth of Christianity. Cambridge: Cambridge University Press.

Brown, R. E. (1977). The Birth of the Messiah: A Commentary on the Infancy Narratives in Matthew and Luke. London: G. Chapman.

Calkins, R. G. (1983). Illuminated books of the middle ages. Ithaca, New York: Cornell University Press.

Campbell, J. (2008). The Hero with a Thousand Faces. Novato, Calif: New World Library.

Carter, W. (2001). Matthew and empire. Harrisburg: Trinity Press International.

Craig, L. B. (2014). Can We Still Believe the Bible? An Evangelical Engagement with Contemporary Ques- tions. Grand Rapids: Brazos.

France, R. T. (1985). The Gospel according to Matthew: an introduction and commentary. Leicester: Inter-Varsity.

Ghose, T. (December 22, 2014). A Christmas Tale: How Much of the Nativity Story is True?. Live Science. n.p.

Gundry, R. H. (1982).Matthew a Commentary on his Literary and Theological Art. Grand Rapids: William B. Eerdmans Publishing Company.

Gundry, R. H. (2000). Salvation in Matthew. In society of Biblical Literature-2000 Seminar Papers. Atlanta: Society of Biblical Literature. 
Harmon, W. \& Holman, C. H. (1992). A Handbook to Literature (6th ed.). New York: Macmillan. Hill, D. (1981). The Gospel of Matthew. Grand Rapids: Eerdmans.

Jones, A. (1965). The Gospel according to St. Matthew. London: Geoffrey Chapman.

Levine, A. J. (1998). Matthew. In C. A. Newsom and S. H. Ringe (Eds.), Women's Bible Commentary. Louisville: Westminster John Knox Press.

Maier, P. L. (1988). The very first Christmas. CPH. Concordia Publishing.

Rapids, G.( 2007). The Gospel of Matthew. In The New International Commentary on the New Testament Series. Cambridge: Eerdmans.

Schaberg, J. (1995). Illegitimacy of Jesus: A Feminist Theological Interpretation of the Infancy Narratives (Biblical seminar series, No 28). Sheffield Academic Press ISBN 1-85075-533-7

Schweizer, E. (1975). The Good News according to Matthew. Atlanta: John Knox Press.

The New Bible Commentary: 21st-century edition. Leicester, UK: Downers Grove, IL: Inter-Varsity Press, 1997.

Vermes, G. (2006). The Nativity: History and Legend. London: Penguin. 